\title{
Bioequivalence and Bioavailability Strikes the Health Management
}

\author{
Rudrarup Gupta* \\ ${ }^{1}$ Commercial Manager, Multifarious Projects Group, India \\ ${ }^{2}$ Overseas Reviewer, World Academy of Science and Technology, USA
}

Submission: March 30, 2017; Published: May 10, 2017

*Corresponding author: Rudrarup Gupta, Commercial Manager, Multifarious Projects Group, India and Overseas Reviewer, World Academy of Science and Technology, USA, Email: rudrarupgupta21@gmail.com

Abstract

As per my envisage Health Care Management is one of the pivotal movements in medical history. Moreover country like India is producing a large number of children each day to recognize its massive population right at this moment. So our medical conception says that, health care problems shall have to be solved by the significant administrative initiatives, which is absolutely conducive to save people within a very short while. Though health care finance and health care control are equally very essential for hospitality implementation through our robust managerial skills. In other words it is having an inextinguishable upon hospitality education and that shall be undoubtedly effective for the students not only to enrich the health care management in a global standard but to refine "Bioequivalence and Bioavailability" in a befitting manner [1].

\section{Global Credence of Bioequivalence and Bioavailability}

The sagacity of Health Care management has the infinite hope to highlight "Pharmaceutical Products" in all over the world. So that, it shall be truly advantageous for both "Bioequivalence and Bioavailability" to be into the best societal nicety already [2].

- The stature and quality of Pharmaceutical Products must be up to the mark.

- $\quad$ Each Hospital/Nursing Home must have the destined training about both "Bioequivalence and Bioavailability".

- Bioequivalence is entirely profitable to elevate the Pharmaceutical business.

- Bioavailability defines the present rate and proportion of drug.

- Both "Bioequivalence and Bioavailability" should have the global importance right now $[3,4]$.

\section{Conclusion}

It is quite justified that, hospitality industry must be depending upon these two very pivotal concepts to recognize their organizations as absolutely comprehensive. So that, it is going to be truly engaging for them to assure the drug medication in an encyclopedic platform already. Above all it is largely related to health care, which emphasizes upon the magnificent health care always, where both "Bioequivalence and Bioavailability" are playing a sheet anchor role to establish the modern technological metamorphosis and that is the exemplary reflection of successful "Health Care" over the forthcoming decades.

\section{References}

1. http://health.oregonstate.edu/degrees/graduate/public-health/ health-management-policy

2. https://www.slideshare.net/muliksudip/bioavailability-andbioequivalence

3. https://www.slideshare.net/AmrutaSambrekar/bioavailabilitystudies

4. http://work.chron.com/role-managers-health-care-16590.html 
Your next submission with Juniper Publishers will reach you the below assets

- Quality Editorial service

- Swift Peer Review

- Reprints availability

- E-prints Service

- Manuscript Podcast for convenient understanding

- Global attainment for your research

- Manuscript accessibility in different formats

( Pdf, E-pub, Full Text, Audio)

- Unceasing customer service

Track the below URL for one-step submission https://juniperpublishers.com/online-submission.php 